\title{
A supramolecular proposal of lignin structure and its relation with the wood properties
}

\author{
HEbER S. ABREU, JOÃo V.F. LATORRACA, REgINA P.W. PEREIRA, MARIA BEATRIZ O. MONTEIRO, \\ FÁBIO A. ABREU and KELYSSON F. AMPARADO
}

Departamento de Produtos Florestais, Instituto de Florestas, Universidade Federal Rural do Rio de Janeiro, BR 465, km 7 23851-070 Seropédica, RJ, Brasil

Manuscript received on June 11, 2007; accepted for publication on July 25, 2008; presented by ELIBIO L. RECH

\begin{abstract}
In spite of the great importance of cellulose the lignin is considered the second most abundant substance of the wood. However, little attention has been given it, mainly to wood properties. The lignin as well as other structural compounds (cellulose and hemicelluloses), has obviously an important role on the wood properties, probably due its composition and existent bonds. In general lignins have $\beta$-O-4 (Alkyl Aril Ether) as majoritary bond. This bond in a continued structure form big molecules with spiral conformation as virtual model. Based on this idea, lignins that have high/low $\beta$-O-4 content may have differentiated spiraled structures, suggesting different behaviors on the wood properties, which shows that the lignins (Guaicyl:Syringyl (GS)) of angiosperms, for example, which have higher $\beta$-O-4 content would present higher spiral conformation than gymnosperms lignins (HG). On the other hand HG lignins have chance of being more anchored on the matrix compound than GS lignins. In this context, the $\beta$-O-4 bonds of lignins possibly affect the wood properties, therefore, it is considered relevant for wood technology science discussion.
\end{abstract}

Key words: lignin, molecular conformation, wood properties, structure.

\section{INTRODUCTION}

The use of wood by human beings began in the prehistory. Currently, wood has been considered a precious raw material whose technological properties contribute to an enormous variety of products. In the civil construction and for other purposes, wood brings comfort, practicality, workability and psychological attenuating properties, as required in a modern society.

Some fast growth trees, such as Eucalyptus, planted in tropical countries, play a certain difficulty for maximize their utilization. Such difficulty justifies the enormous investment in research to optimize wood properties, in order to increase beneficial properties and lower production costs.

Most of the studies on wood properties have been

Correspondence to: Heber dos Santos Abreu E-mail: Abreu@ufrrj.br based on the cellulose deposition, microfiber orientation, grain angle, cellulose polymerization and crystallinity degree (Conrad et al. 2003). Larger microfiber angle, for example, is associated with low tensile strength resulting in reduced strength of wood and spiral grain occurrence with degree of longitudinal shrinkage. Aspects of growth have also been shown to be important, as can be noticed on mature woods that are better and have a greater acceptance than juvenile woods (Haygreen and Bowyer 1982).

Conrad et al. (2003) in their review reported that one of the greatest wood problems is the cracking and classified this phenomenon in three types of propagation: Mode I, II and III according to intercellular fracture, intracellular crack and crack deflection. These problems also occur during drying, resulting in collapse and wood shrinkage. Wood defects, such as honeycomb, ring fail- 
ure and box-heart split have also been reported. Such problems can be attenuated by special drying in optimized schedules. The problems of growth tension, for example, have also been the target of a large number of studies (Rasps et al. 2000, Latorraca and Albuquerque 2000, Donaldson 1995), especially with Eucalyptus spp, though mostly with an exclusively physical focus. It is our basic premise that a number of physical and mechanical properties may be driven by lignin, rather than cellulose. So, what would demonstrate that lignin has a significant role in the wood properties? This issue has been poorly reported in the literature, which forced us to reflect on the importance of the fragility and rigidity of lignin molecules regarding the wood properties. It is known that lignin is responsible for the reinforcement of cell walls and the middle layer in all woody plants, and that its absence would make tree life impossible under gravity force. The composition, molecular structure and spatial orientation of lignin surely contribute to wood properties more than we have previously supposed (Bidlack et al. 1992).

As reported previously, the lignins of different neighbor cells between Fiber $\times$ Fiber, Ray $\times$ Ray, Vessel $\times$ Vessel and Fiber $\times$ Ray, Fiber $\times$ Vessel, Vessel $\times$ Ray border regions of the cell middle layer (Middle Layer (ML) and Cell Corner (CC)) sustained different basic composition ratios (Table I). The higher $p$-Hydroxyphenylpropane (H) and Guaiacylpropane $(\mathrm{G})$ units content can take a certain molecular complexity, therefore these lignins play different behaviors related to the number of inter bonds and cross-linkages with the matrix compound (Fig. 1). The MLcc lignin of the Fiber $\times$ Ray region, for example, has been shown to maintain the highest rigidity levels. This region is always working under compression and tension forces.

According to Plomion et al. (2000) in Eucalyptus and Pinus there are strong relationships between growth strain and wood characteristics, such as wood density, longitudinal and tangential shrinkages, longitudinal modulus of elasticity, anatomical characteristics (microfiber angle), and chemical composition (lignin content, ratio of lignin monomerics units, hemicellulose, and cellulose content). Study of the lignin model compound have been carried out by near-field scanning optical and atomic force microscopy, revealing that Dehydrogenase
Polymer (DHP) synthesizes present globule supramolelecular assembly supporting the idea that layered supramolecular assemblies patched from the regions of different rheological properties (Micic et al. 2004). The construct oligomers for different diasteroisomers (Alkyl Aril Ether), has taken to several hypotheses of structural conformational shape (Langer et al. 2007).

\section{LIGNIN STRUCTURE}

The variation of the number of intermonomeric bonds is in agreement with the hypothesis that the combination among precursors gives rise to different molecules structures (Fig. 2).

The estimation of higher syringyl unit as in Guaiacyl:Syringyl (GS) lignin for example, favor a direct relation with $\beta$-O-4 (Alkil Aril Ether) content, indicating a lignin molecule with a high structural simplicity (Table II). This type of lignin is normally found in hardwood, revealing a small number of intermonomeric bonds as well as a small number of cross-linkages with the matrix compound as hypothesis. This fact can be conditioned by the structural profile, on the hypothesis of that the higher molecular linearity as in GS lignin, could contribute to rupture of the middle lamella among cell wall more than the HG lignin.

To clear the understanding about the behavior of lignin on wood properties, we design a virtual molecule with the $\beta$-O-4 composition only. Analyzing on this point of view this molecule would present a chain with a higher spiral conformation, while molecules with a composition of the $\beta-\beta$ and $\beta-5$ alone, would play a low spiral conformation. Thus a molecule rich in $\beta$ O-4 bond would sustain a low degree of cross linkage, while molecules with considerable $\beta-\beta$ and $\beta-5$ content would have a higher possibility of former cross linkage with matrix compound. This kind of molecule (lignin) presents lower expansion and flexibility properties than (GS) lignins, show to be a system with higher rigidity molecular. According to our idea, the lignins may have spiral conformation, as well as their occurrence with other cell wall compounds. This may be supported by structural protein (Dey and Harbone 1997, Cassab 1998, Carpita et al. 1993), which presents an helix chain and it has been an indicator of a regulatory system between proteins and wood compression formation that presents 
TABLE I

Guaiacyl/Syringyl ratio in the lignins of birch cells (Higuchi 1984, Abreu et al. 1999) and their structural and rigidity level, respectively.

\begin{tabular}{c|c|c|c}
\hline $\begin{array}{c}\text { Morphological } \\
\text { regions }\end{array}$ & $\begin{array}{c}\text { Guaiacyl:Syringyl } \\
\text { ratio }\end{array}$ & $\begin{array}{c}\text { Probable types of } \\
\text { lignin structures }\end{array}$ & $\begin{array}{c}\text { Molecular rigidity } \\
\text { level }\end{array}$ \\
\hline Fiber S2 (F) & $12: 88$ & No condensed & Low rigidity \\
\hline Vessel S2 (V) & $88: 12$ & Condensed & Rigid \\
\hline Ray parenchyma & $49: 51$ & Semi-condensed & Moderated rigidity \\
\hline MLcc (F/F) & $91: 9$ & Condensed & Rigid \\
\hline MLcc (F/V) & $80: 20$ & Condensed & Rigid \\
\hline MLcc (F/R) & $100: 0$ & Condensed & High rigidity \\
\hline MLcc (R/R) & $88: 12$ & Condensed & Rigid \\
\hline
\end{tabular}

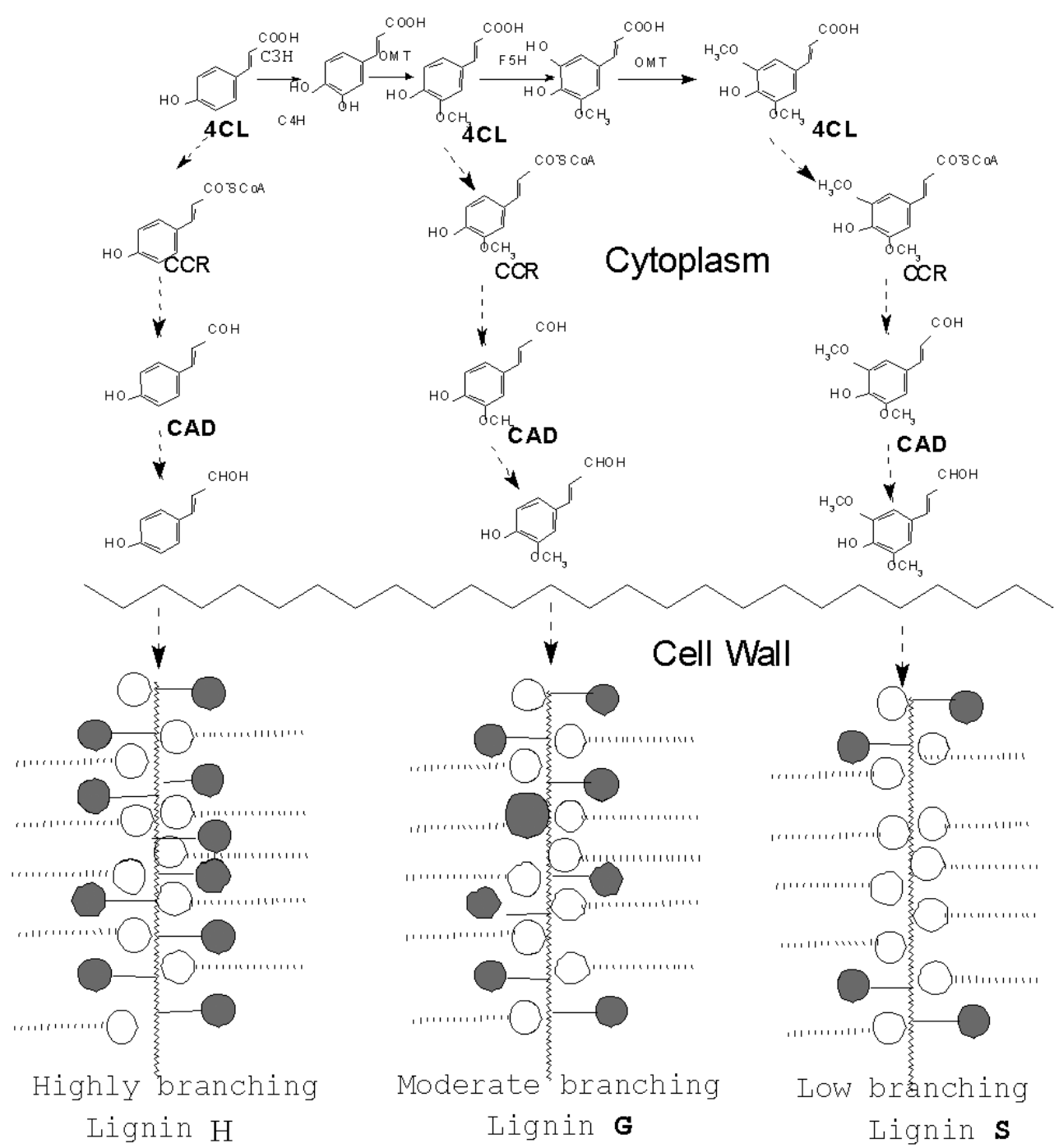

Fig. 1 - Syringyl and Guaiacyl lignins biosynthesis (pre-polymerization). PAL-Phenylalanine Amonia-lyase, C3H-4-Hydroxycinnamate-3-hydroxylase, 5H-Ferulate-5-hydroxylase, OMT-5-Adenosyl-methyonine:caffeate/5Hydroxyferulate-O-ethyltransferase, 4CL-Hydroxycinnamoyl:CoA ligase, CCR-Hydroxycinnamyl:CoA reductase, CAD-Cinnamyl alcohol dehydrogenase, C4H-Cinnamate-4-hydroxylase 


\section{SPIRAL CONFORMATION}
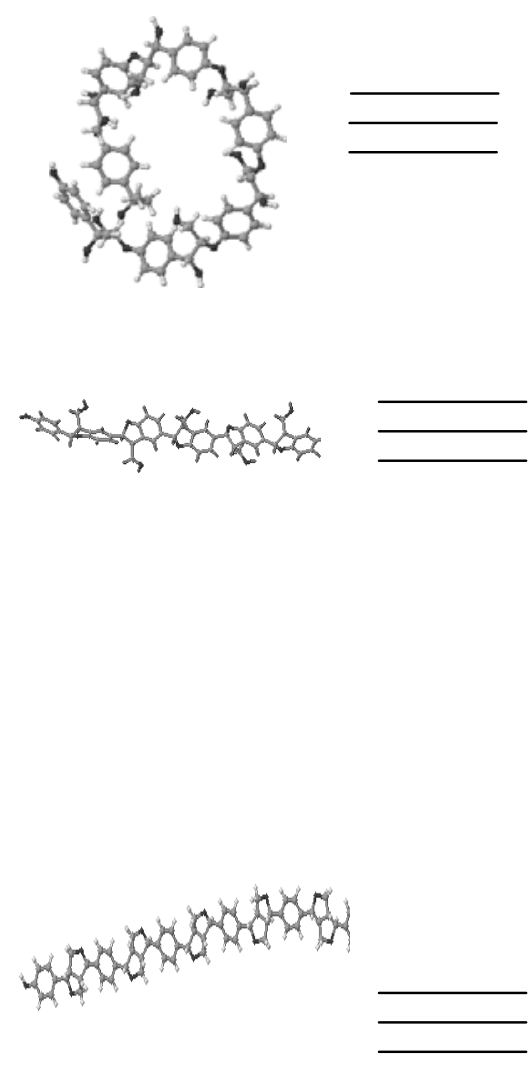

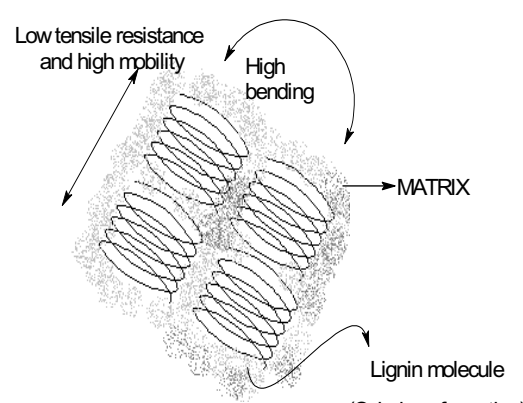

(Spiral conformation)

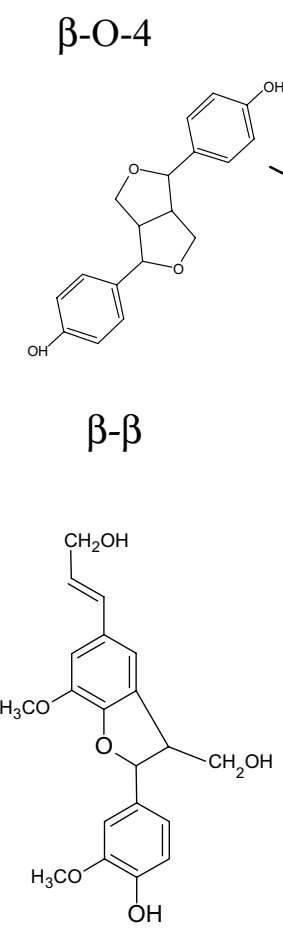

$\beta-5$

Fig. 2 - Proposal of a structural profile of lignin molecule with $\beta$-O-4, $\beta-\beta, \beta-5$, respectively (first figure) and (second figure).

different types of lignins (Bao et al. 1992, Plomion et al. 2000). A computer-assisted structure elucidation and molecular simulation suggested that the lignin biopolymers have an helical structure characteristic of many naturally synthesized molecules (Faulon and Hatcher 1994), on the other approaches a synthetic $\beta$-O-4 type artificial lignin was consider a linear polymer with well-defined structure (Kishimoto at al. 2006). Cellulose and hemicellulose have also a spiraled conformation, which contribute to the high stability of the cell wall. Examples of spiral deposition are also observed in the microfiber orientation in the wall as well as the thickness in the in- ner layer of the cell. It may contribute to understand the lignin conformation according to our suggestion, however, it is common to say that the anatomical characteristics and cellulose microfiber orientation are responsible for most of the wood properties.

A simple relation can be observed between softwoods and hardwood, which have significant different properties. A simple comparison among the average of MOR/SG (Modulus of Rupture/Specific Gravity), MOE/ SG (Modulus of Elasticity/Specific Gravity) and Compression Parallel to Grain/Specific Gravity, result, respectively, in the values of $168.91 \mathrm{Mpa} /(\mathrm{g} / \mathrm{cm}), 23.61 /$ 
TABLE II

IFM estimated values of Björkman lignins from softwood and hardwood (Abreu et al. 1999).

\begin{tabular}{c|c|c|c|c|c}
\hline Plant & $\begin{array}{c}\beta \text {-O-4 } \\
(\%) \text { average }\end{array}$ & IMF & $\begin{array}{c}\text { Type of } \\
\text { lignin }\end{array}$ & Rigidity & $\begin{array}{c}\text { Structural } \\
\text { profile }\end{array}$ \\
\hline Softwood (tree) & 40.20 & 0.67 & HG & Moderated & Branching \\
\hline Hardwood (tree) & 71.04 & 2.45 & GS & Low & Branching \\
\hline \multicolumn{7}{c}{ IFM - Index of Molecular Flexibility. }
\end{tabular}

$\left(\mathrm{g} / \mathrm{cm}^{3}\right)$ and $96.52 /\left(\mathrm{g} / \mathrm{cm}^{3}\right)$ and $159.68 /\left(\mathrm{g} / \mathrm{cm}^{3}\right), 19.84 /$ $\left(\mathrm{g} / \mathrm{cm}^{3}\right)$ and $81.61\left(\mathrm{~g} / \mathrm{cm}^{3}\right)$ (Wood Handbook 1999). The data were adjusted dividing the Modulus values by Specific Gravity, in order to make comparison possible. The MOR, MOE and Compression parallel to grain were higher for softwood (gymnosperm) than hardwood (angiosperm). Of course, several characteristics may also be working together, (anatomical, physical, chemical characteristics). In this case, what would be the lignin contribution? If the softwood lignin (HG) plays low spiraled conformation, probably there will be a higher number of cross links, lower longitudinal expansion and higher bend level than (GS) lignin (Fig. 2). If it is true as we imagine, this hypothesis can open new perspectives in the fields of the wood technology science.

\section{CONCLUSION}

The spiral conformation hypothesis allows us to propose ideas regarding special tissues, like wood tension and compression, on wood properties, as well as on the wood as a whole, correlating $\beta$-O-4 bonds content with gymnosperm and angiosperm woody plants. Therefore, softwood species produce stable HG lignin. It means that this group of trees forms a net of inter and intra-molecular bonds in the cell wall larger than angiosperm. Above all, further evidence may provide new tools towards understanding wood properties at a molecular level, so that possible defects and other problems may be corrected, causing less waste and damage after tree harvest. The application of this hypothesis mentioned above, stimulates new fields in the forest science. The alterations of lignin composition from GS to $\mathrm{HG}$, for example, would reinforce the border region among the walls of xylem cells, resulting in a greater resistance to the forces of growth tension and cell wall rupture.

\section{ACKNOWLEDGMENTS}

The authors thank Fundação Carlos Chagas Filho de Amparo a Pesquisa do Estado do Rio de Janeiro (FAPERJ) and Coordenação de Aperfeiçoamento de Pessoal de Nível Superior (CAPES) for financial support.

\section{RESUMO}

Apesar da grande importância da celulose a lignina é considerada a segunda substância mais abundante da madeira. Entretanto, pouca atenção tem sido dada a ela, principalmente com relação às propriedades da madeira. A lignina assim como outras substâncias (celulose e hemicelulose), tem obviamente um papel importante sobre as propriedades da madeira, provavelmente devido a sua composição e a existências de ligações. Geralmente as ligninas possuem majoritariamente ligações $\beta$-O-4 (Éter Alquil-Arílico), esta ligação em uma estrutura contínua forma grandes moléculas com conformação em espiral, como visto em modelo virtual. Com base nesta idéia, ligninas que possuem alto/baixo teor de $\beta$-O-4, podem ter estruturas espiraladas diferenciadas, sugerindo comportamentos diferentes sobre as propriedades da madeira. Isto mostra que as ligninas de angiospermas ((Guaicílica:Siringilica) (GS)), que possuem mais alto teor de $\beta$-O-4, por exemplo, apresentariam uma conformação mais espiralar do que as ligninas de gimnospermas (HG). Por outro lado, as ligninas HG possuem mais chances de serem ancoradas sobre a substância matriz do que as ligninas GS. Neste contexto, ligações $\beta$-O-4 das ligninas afetam as propriedades da madeira, portanto, isto pode ser considerado relevante para discussão em ciência e tecnologia da madeira.

Palavras-chave: lignina, conformação molecular, propriedades da madeira, estrutura. 


\section{REFERENCES}

Abreu HS, Miguel AM and Maria MA. 1999. Lignin and Structure. Wood and Fiber Sci 4: 426-433.

Bao W, OMalley DM and Sederoff RR. 1992. Wood contain a cell-wall structural protein. Proc Natl Acad Sci 89: 6604-6608.

Bidlack J, Malone M and Benson R. 1992. Molecular structure and component integration of secondary cell wall in plants. Proc Okla Acad Sci 72: 51-56.

CARPita NC AND Gibeaut DM. 1993. Structural models of primary cell walls in flowering plants: consistency of molecular structure with the physical properties of the walls during growth. Plant J 1: 1-30.

CASsaB GI. 1998. Plant cell wall protein. Annu Rev Plant Physiol Plant Mol Biol 49: 281-309.

Conrad MPC, Smith GD And Ferlund G. 2003. Fracture of solid wood: A review of structure and properties at different length scales. Wood and Fiber Sci 4: 570-584.

DEY PM AND HARBONE JB. 1997. Plant Biochemistry, Academic Press, NY.

DONALDSON LA. 1995. Cell wall fracture properties in relation to lignin distribution and cell dimensions among three genetic groups of radiate pine. Wood Sci Technol 1: 29: $51-63$.

FAULON J-L AND HATCHER PG. 1994. Is there any order in the structure of lignin? Energy and Fuel 8: 402-407.

HAYGREEN JJ AND BOWYER JL. 1982. Forest products and wood science (an introduction). The Iowa State University Press, Iowa.
HiguCHI T. 1984. Biosynthesis and biodegradation of wood components. Academic Press, New York, USA.

Kishimoto T, Uraki Y and Ubukata M. 2006. Chemical synthesis of $\beta-\mathrm{O}-4$ type artificial lignin. Org Biomol Chem 4: 1343-1347.

LAnger V, Lundquist K And PARKAs J. 2007. Stereochemistry of guaiacyl lignin. Bio Res 2: 590-597.

LATORRACA JVF AND AlbuQUERQUe CEC. 2000. Efeito do rápido crescimento sobre as propriedades da Madeira. Floresta e Ambient 7: 279-291.

Micic M, RAdotic K, Jeremic M, DJiKANovic D AND KÄMMER SB. 2004. Study of the lignin model compound supramolecular structure by combination of nearfield scaning microscopy and atomic force microscopy. Colloids and Surfaces B: Bionterfaces 34: 33-40.

Plomion C, Pionneau C, Brach J, Costa P And BailLÈrES H. 2000. Compression wood-responsive proteins in developing xylem of maritime pine (Pinus pinaster Ait) American Society of Plant Physiologists. Plant Physiol 3: 959-970.

RASPS IL, GARCIA JN AND WALNUT MCS. 2000. Influence of the it thin in the tensions of growth of Eucalyptus grandis Hill former-maiden. Sci For 58: 111-125.

WOOD HANDBOOK. 1999. Wood engineering material. Gen./twch. Rep. FPF-GTR-113, Madison, WI, USA. 